$0 \mathrm{CT} 17199601$ ENGINEERING DATA TRANSMITTAL
Sta. 15

\begin{tabular}{l|}
\hline 2. To: (Receiving organization) \\
RFSH/Evaporator Plant Eng. \\
\hline 5. Proj./Prog./Dept./Div.: \\
AP Temperature Display \\
Upgrade
\end{tabular}

3. From: coriginating Organization) FDNW/Control Systems Eng.

6. Cog. Engr.:

JL Dowel1

Page 1 of

1. EDT 157980

8. Originator Remarks:

Routed for approval and release

9. Equip./Component No.:

N/A

10. System/Bldg./Facility:

241-AP-271

11. Receiver Remarks:

12. Major Assm. Dwg. No.: N/A

13. Permit/Permit Application No.: N/A

14. Required Response Date: ASAP

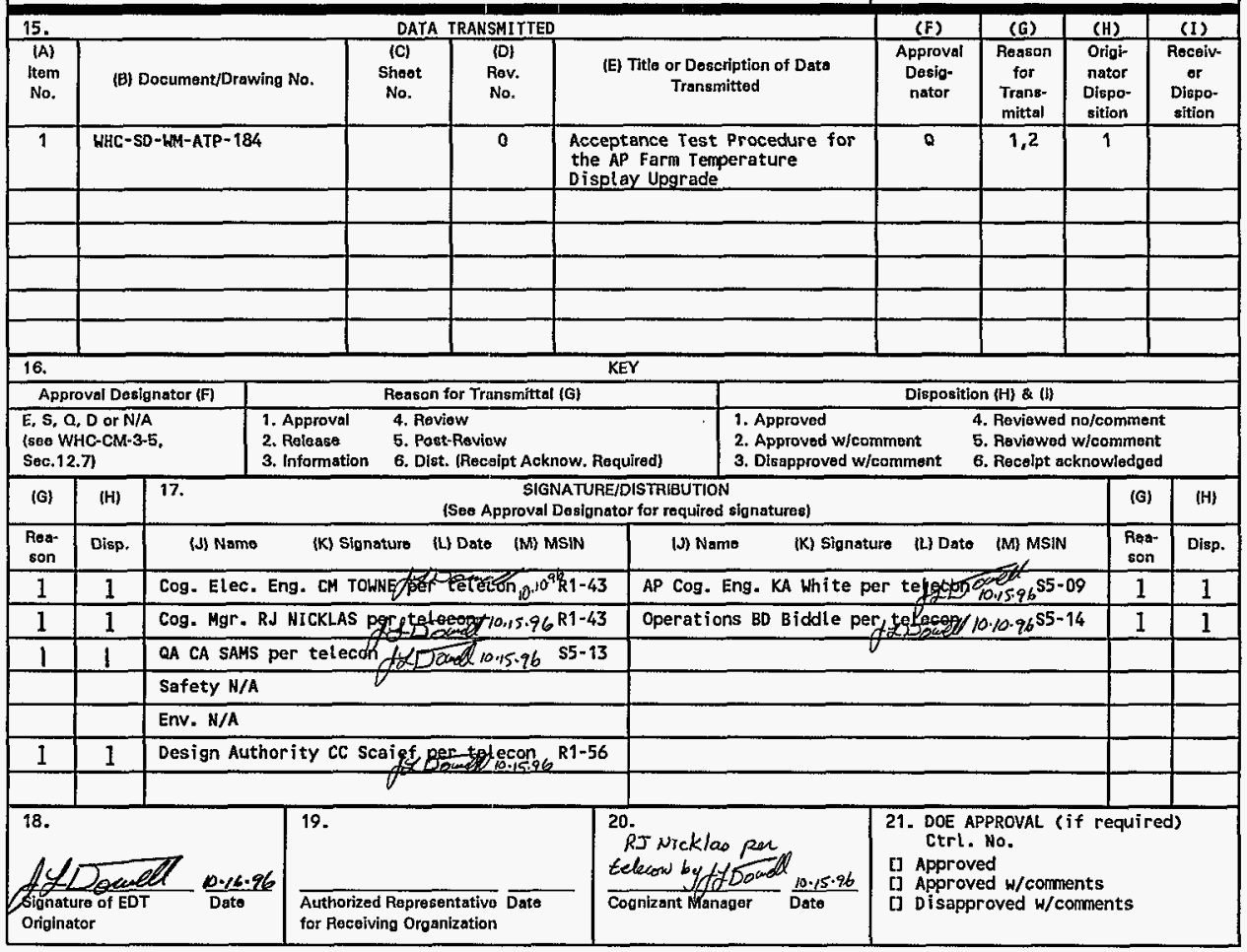

BD -7400-172-2 (04/94) GEF097 


\title{
Acceptance Test Procedure for the AP Farm Temperature Display Upgrade
}

\author{
JL DOWELL \\ for Westinghouse Hanford Co., Richland, WA 99352 \\ U.S. Department of Energy Contract DE-AC06-87RL10930 \\ kN \\ EDT/ECN: EDT-157980 \\ UC: 721 \\ Org Code: 47657600 \\ Charge Code: E55266/N1174 \\ B\&R Code: EW3120071 \\ Total Pages: 39 \\ KN \\ Key Words: Temperature, Data Acquisition, Datalogger, Temperature \\ Monitoring, Westronic, AP Tank Farm \\ Abstract: The purpose of this procedure is to document the Westronic \\ Data units function as intended as installed at 241-AP-271 tank farm.
}

TRADEMARK DISCLAIMER. Reference herein to any specific comercial product, process, or service by trade name, trademark, manufacturer, or otherwise, does not necessarily constitute or imply its endorsement, recotmendation, or favoring by the United States Government or any agency thereof or its contractors or subcontractors.

Printed in the United States of America. To obtain copies of this document, contact: WHC/BCS Document Control Services, P.O. Box 1970, Mailstop H6-08, Richland WA 99352, Phone (509) 372-2420; Fax (509) 376-4989.
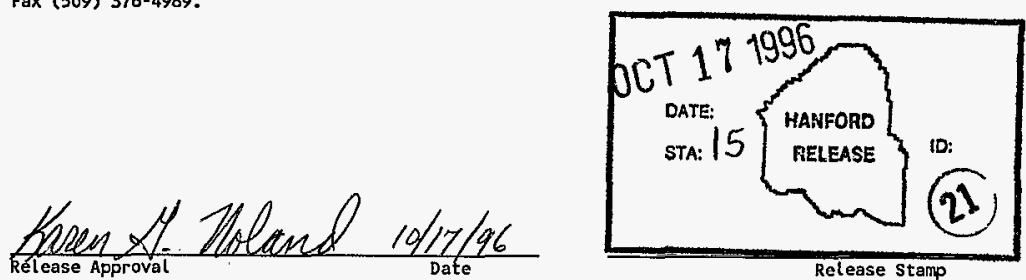

Approved for Public Release 


\section{CONTENTS}

1.0 INSTRUCTION SECTION .................... 1

1.1 PURPOSE/SCOPE . . . . . . . . . . . ... 1

1.2 DESCRIPTION OF THE SYSTEN $\ldots \ldots \ldots \ldots \ldots$

1.3 CRITERIA $\ldots \ldots \ldots \ldots \ldots$

1.4 REFERENCES $\ldots \ldots \ldots \ldots 2 \ldots$

1.4.1 Drawings . . . . . . . . . . . . . 2

1.4 .2 other ......................... 2

1.4 .3 Procedures . . . . . . . . . . . . . . 2

1.5 RESPONSIBILITIES ................. 2

1.5.1 Project Engineer . . . . . . . . . . . . . 2

1.5 .2 Test Director ................. 3

1.5.3 Recorder .................... . . 4 4

1.5 .4 Quality ................... 4

1.5.5 0ther Personnel . . . . . . . . . . . . 5

1.6 TEST CONDITIONS \& EQUIPMENT REQUIRED $\ldots \ldots \ldots \ldots \ldots$

1.6.1 Test Conditions . . . . . . . . . . 5

1.6.2 Equipment Required . . . . . . . . . . . . 5

1.7 ACCEPTANCE TEST SETUP ................. 6

1.7.1 Prel iminary Conditions ............. 6

1.8 ACCEPTANCE TEST ................... 8

1.8.1 Testing communication of TDS-AP-1 to each multiplexer : 8

1.8.2 Compare TDS-AP-1 readings to MUX readings . . . . . 8

1.8.3 Testing communication of TDS-AP-2 to each multiplexer : 10

1.8 .4 Compare TDS-AP-2 readings to HUX readings . . . . . 10

1.9 ACCEPTANCE TEST CLOSURE . . . . . . . . . . . . . 12

1.10 TEST DATA SHEETS . . . . . . . . . . 13

1.11 TEST LOG SHEET . . . . . . . . . . . . . 13

1.12 DIGITAL DISPLAY UNIT: SELF TESTS PERFORMED AT POHER ON. $\ldots 14$

2.0 CHANGE CONTROL AND EXCEPTIONS TO ACCEPTANCE TEST SECTION . . . . 17

2.1 ACCEPTANCE TEST PROCEDURE CHANGE CONTROL . . . . . . . 17

2.2 TEST EXECUTION ....................... 17

2.2.1 Without Exception ............. 17

2.2.2 With Exception(s) Resolved ............ 17

2.2.3 With Exception(s) Outstanding .......... 17

3.0 RECORDING AND RESOLVING EXCEPTIONS . . . . . . . . . . . . . 18

3.1 GENERAL . . . . . . . . . . . . . . . ... 18

3.2 RECORDING . . . . . . . . . 18

3.3 RETEST/RESOLUTION . . . . . . . . 18

3.4 APPROVAL AND ACCEPTANCE . . . . . . . . . . . . . . . . 19

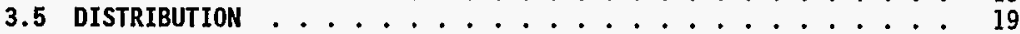

APPENDIX A TEST DATA SHEETS ................... 20

APPENDIX B TEST EXCEPTION SHEET .................. 32

APPENDIX C TEST LOG SHEET $\ldots \ldots \ldots$

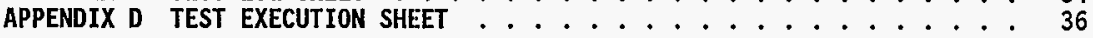


WHC-SD-WM-ATP-184

Revision 0

\section{ACCEPTANCE TEST PROCEDURE FOR THE AP FARM TEMPERATURE DISPLAY UPGRADE}

\subsection{INSTRUCTION SECTION}

\subsection{PURPOSE/SCOPE}

The purpose of this document is to demonstrate that new Temperature Displays installed at 241-AP-27l tank farm (replacing the obsolete temperature displays) operate as expected. Actual test execution steps begin in Section 1.7. A11 portions of the test shall be completed before the test results are either accepted or rejected. Testing is expected to take less than 3 days to complete.

The purpose of this procedure is to verify correct operation of the Westronic 3200/MB Temperature Display units. Acceptance testing wil] verify that the configured hardware functions according to intent prior to operational use. Note: the capability to communicate via the MODBUS port and/or modem is not tested in this procedure.

\subsection{DESCRIPTION OF THE SYSTEN}

Each of the two Temperature Displays are connected to 8 multiplexers, and each multiplexer is attached to over 60 thermocouples each. Each Temperature Display has its serial port (MODBUS) connected to modem so that the temperature readings can be relayed to TMACS.

\subsection{CRITERIA} met:

This Test Procedure will be successful if all the following criteria are

1.3.0.1 Each Temperature Display indicates there are no problems when power is applied.

1.3.0.2 Each Temperature Display responds appropriately to the change induced at the multiplexer terminats.

1.3.0.3 Readings taken with each Temperature Display match readings taken at the MUX selector switch within \pm 7 degree $F( \pm 3.9$ degree $C)$. 
WHC-SD-WM-ATP-184

Revision 0

\subsection{REFERENCES}

\subsubsection{Drawings}

- H-2-90489, INSTRUMENTATION ENGINEERING BLOCK DIAGRAM.

- H-2-90494, (SHT 7) INSTM XMTR/MUX ENCLOSURE TYPE A

- H-2-90494, INSTM TEMP DISPLAY INTERCONNECTION DIAG

- H-2-90496, INSTM PANEL \& RACK ARRANGEMENTS

\subsubsection{0ther}

- User Manual, Westronics Series 3200/MB Multibank Digital Data Recorder, Manual Part No. M0100124-01.

\subsubsection{Procedures}

- T0-040-660, OBTAIN/RECORD DOUBLE SHELL TANK TEMPERATURE DATA

- T0-270-040, OPERATE 241-AP TEMPERATURE DISPLAY SYSTEM (TDS)

- TF-OR-A-03, OPERATOR ROUND SHEETS - AP, AW TANK FARMS AND LERF

\subsection{RESPONSIBILITIES}

Each organization participating in the execution of this test procedure will designate personnel for the responsibilities and duties as defined herein for their respective roles. The names of these designees shall be provided to the Recorder for listing on the Recorder's copy of the Test Execution Sheet prior to the performance of any part of this test procedure.

Al1 individuals shall carry out their assigned work in a safe manner to protect themselves, others, and the equipment from undue hazards and to prevent damage to property and environment. Performance of test activities shall always include safety and health aspects as delineated in the operations manuals and as directed by the Project Engineer. Any hazard identified during the performance of this test procedure shall be reported to the Test Director.

\subsubsection{Project Engineer}

\subsubsection{Designate a Test Director.}

1.5.1.2 Coordinate testing with facility management.

1.5.1.3 Act as liaison between the test participants.

1.5.1.4 Ensure informal testing and inspection is complete.

1.5.1.5 Schedule and conduct a pre-test meeting with participants prior to start of testing.

1.5.1.6 Notify the persons performing and witnessing the test prior to the start of testing.

1.5.1.7 Notify all concerned parties when a change is made in the testing schedule. 
1.5.1.8 Approve field changes to this test procedure.

1.5.1.9 Sign/date test execution sheet (Appendix D) when test procedure is approved and accepted.

1.5.1.10 Take necessary action to clear test exceptions.

1.5.1.11 Sign/date Test Exception Sheet (Appendix B) when an exception has been resolved.

1.5.1.12 Provide a distribution 7 ist for the approved and accepted test procedure.

1.5.1.13 Confirm that a11 equipment required for performing this test, as listed in Section 1.6.2, will be available for the test duration.

1.5.1.14 Provide equipment required for performing this test, which has not been designated as being provided by others.

\subsubsection{Test Director}

1.5.2.1 Witness the tests.

1.5.2.2 Coordinate a11 testing.

1.5.2.3 Confirm that shop testing (if any) and/or inspection (if any) of the test unit(s) or portion of the test unit(s) have been completed.

1.5.2.4 Stop any test which may cause damage to the test unit(s) until the test procedure has been revised.

1.5.2.5 Approve field changes to this test procedure.

1.5.2.6 Obtain revisions to this test procedure, as necessary, to comply with authorized field changes or to accommodate existing field conditions.

1.5.2.7 Evaluate recorded data, discrepancies, and exceptions.

1.5.2.8 Obtain from the Project Engineer, any information or changes necessary to clear or resolve exceptions.

1.5.2.9 Sign/date Test Data sheets and Test Execution sheet (Appendix A \& D) when execution of this test procedure has been completed.

1.5.2.10 Sign/date Test Exception Sheet (Appendix B) when acceptable retest has been performed.

1.5.2.11 Prepare and obtain required signatures on the Test Report prior to reproduction and distribution. 
WHC-SD-WM-ATP-184

Revision 0

\subsubsection{Recorder}

1.5.3.1 Witness testing and perform all recording using black ink.

1.5.3.2 Record names of all designated personnel on the Test Execution sheet (Appendix D) on the Recorder's copy of test procedure prior to testing.

1.5.3.3 0bserve tests, record test data and maintain Test Log (Appendix C).

1.5.3.4 Sign/date the Test Execution Sheet, Test Data sheets and Test Exception sheet(s) (Appendices A, B \& D) as the Recorder.

1.5.3.5 "Checkoff" every test step on the Recorder's copy as it is completed, next to the step number and under the appropriate gauge identifier.

1.5.3.6 Record authorized field changes to this test procedure.

1.5.3.7 Record, on a Test Exception Sheet, exceptions and test steps that are either modified or are not performed. Additional Test Exception Sheets can be reproduced as needed (Appendix B).

1.5.3.8 Orally notify the Test Director at the time an objection is made.

1.5.3.9 After the test procedure is complete assign page numbers to Test Exception Sheets.

1.5.3.10 Submit the completed test procedure to the Test Director for approval signatures and distribution.

\subsubsection{Quality}

1.5.4.1 Witness the tests.

1.5.4.2 Evaluate recorded data, discrepancies, and exceptions.

1.5.4.3 Approve field changes to this test procedure.

1.5.4.4 Sign/date Test Execution Sheet (Appendix D) when execution of this test procedure is completed and again when it is approved and accepted.

1.5.4.5 Sign/date Test Exception Sheet (Appendix B) when an exception is made and again when it has been resolved.

1.5.4.6 Initial/mark Test Data sheets (Appendix A), assuring data is entered correctly. 
WHC-SD-WM-ATP-184

Revision 0

\subsubsection{0ther Personnel}

1.5.5.1 Instrument Technician(s) familiar with Westronic data recorder(s) and AP farm Multiplexers.

\subsection{TEST CONDITIONS \& EQUIPMENT REQUIRED}

\subsubsection{Test Conditions}

No unique or unusual chemical, fire, release of energy, or criticality safety hazards involved with performing or supporting these tests have been identified. Normal facility safety rules and procedures shall be followed during these tests. All electrical and mechanical apparatus shall be operated as designed.

The test items, equipment, and facilities used in this test procedure are not expected to be affected permanently by this procedure. Test equipment that has been damaged shall be repaired or replaced.

\subsubsection{Equipment Required}

The Project Engineer shall assure all test equipment is available unless otherwise noted. The following list is provided as an aid and is not intended to be an exhaustive list.

- Jumper wire (about 6 inches long) with leads.

- Potentiometer, for type $E$ thermocouples

- Hand Tools

- User Manual, Westronics Series 3200/MB Multibank Digital Data Recorder, Manual Part No. M0100124-01. 
WHC-SD-WM-ATP-184

Revision 0

\subsection{ACCEPTANCE TEST SETUP}

\section{Step Checkoff and Data Sheet Entries}

Spaces for the Recorder to "check off" are provided to the left of the step numbers as the step is completed. Each RECORD, RECORD

VERIFICATION, or VERIFY in a step requires an entry on the data sheets; the data sheets include the step numbers.

\subsubsection{Preliminary Conditions}

1.7.1.1 The prejob meeting with test participants has been held and the personnel involved in the test understand their roles.

1.7.1.2 Assure the modems, the Temperature Displays, and associated equipment are plugged in. If needed, plug in any equipment being tested.

1.7.1.3 Assure the modems are turned ON. If needed, turn oN the modem(s) power switch.

1.7.1.4 Assure both the Temperature Displays are turned OFF.

\section{INFORMATION}

This section checks that each display does not show an error code pertailling to an internal problem.

1.7.1.5 Turn the power to TDS-AP-1 ON. VERIFY that TDS-AP-1 passes all internal hardware and software self diagnostics as described in Section 1.12.

1.7.1.6 For each of the following parameters read the value from TDS$A P-1$. If the value is different from that shown, change the value to match. RECORD VERIFICATION for each item in the test data sheet.

- Date/Time is current ?

- Printer status? 
WHC-SD-WM-ATP-184

Revision 0

1.7.1.7 Turn the power to TDS-AP-2 ON. VERIFY that TDS-AP-2 passes all internal hardware and software self diagnostics as described in Section 1.12.

1.7.1.8 For each of the following parameters read the value from TDS$A P-2$. If the value is different from that shown, change the value to match. RECORD VERIFICATION for each item in the test data sheet.

- Date/Time is current ?

- Printer status? 


\subsection{ACCEPTANCE TEST}

1.8.1 Testing communication of TDS-AP-1 to each multiplexer

\section{INFORMATION}

Procedures in this section serve to verify and validate the communication capabilities of TDS-AP-1 to each multiplexer by shorting a selected thermocouple and verifying the response changed appropriately.

1.8.1.1 In 241-AP-271 use TDS-AP-1 to read the value of point 001 (TE-101-1). RECORD the reading.

1.8.1.2 At Tank AP-101, on multiplexer MUX-101-1: use the jumper to. short the terminals the thermocouple in the previous step are attached.

1.8.1.3 VERIFY the reading changed.

1.8.1.4 Remove the jumper and VERIFY the reading is the same as the value of the prior reading \pm 2 degrees $F(0 \pm 1$ degrees $C)$.

1.8.1.5 Repeat steps 1.8.1.1 through 1.8.1.4 inclusive for the following thermocouples (located at the following multiplexers):

\begin{tabular}{|c||c|c|c|}
\hline TDS-AP-1 Point No. & Tank No. & $\begin{array}{c}\text { MuTt iplexer } \\
\text { No. }\end{array}$ & $\begin{array}{c}\text { Thermocouple } \\
\text { No. }\end{array}$ \\
\hline 072 & AP-101 & MUX-101-2 & TE-101-72 \\
\hline 141 & AP-102 & MUX-102-1 & TE-102-21 \\
\hline 194 & AP-102 & MUX-102-2 & TE-102-94 \\
\hline 285 & AP-103 & MUX-103-1 & TE-103-45 \\
\hline 310 & AP-103 & MUX-103-2 & TE-103-70 \\
\hline 420 & AP-104 & MUX-104-1 & TE-104-60 \\
\hline 439 & AP-104 & MUX-104-2 & TE-104-79 \\
\hline
\end{tabular}

\subsubsection{Compare TDS-AP-1 readings to MUX readings}

1.8.2.1 In the Test Data sheet, RECORD the calibration number and expiration date of the Type $E$ instrument.

1.8.2.2 In 241-AP-271 use TDS-AP-1 to read the value of points in the following table; RECORD the readings. 
1.8.2.3 At each multiplexer use the type $E$ instrument to obtain the readings for the temperature elements 1 isted in the following table; RECORD the readings.

1.8.2.4 VERIFY the difference between readings made with the TDS-AP-1 and the field reading is less than 7 degrees $F$ ( 3.9 degrees

C) for each thermocouple.

\begin{tabular}{|c|c|c|}
\hline TDS-AP-1 Point No. & Tank No. & $\begin{array}{c}\text { Thermocouple } \\
\text { No. }\end{array}$ \\
\hline 052 & \multirow[t]{6}{*}{ AP-101 } & $T E-101-52$ \\
\hline 046 & & TE-101-46 \\
\hline 042 & & $T E-101-42$ \\
\hline 040 & & $T E-101-40$ \\
\hline 038 & & TE-101-38 \\
\hline 036 & & $T E-101-36$ \\
\hline 172 & \multirow[t]{6}{*}{ AP-102 } & $T E-102-52$ \\
\hline 166 & & $T E-102-46$ \\
\hline 162 & & $T E-102-42$ \\
\hline 160 & & $T E-102-40$ \\
\hline 158 & & TE-102-38 \\
\hline 156 & & $T E-102-36$ \\
\hline 290 & \multirow[t]{6}{*}{$A P-103$} & $T E-103-52$ \\
\hline 286 & & $T E-103-46$ \\
\hline 282 & & $T E-103-42$ \\
\hline 280 & & $T E-103-40$ \\
\hline 278 & & TE-103-38 \\
\hline 276 & & $T E-103-36$ \\
\hline 412 & \multirow[t]{6}{*}{ AP-104 } & TE-104-52 \\
\hline 406 & & $T E-104-46$ \\
\hline 402 & & $T E-104-42$ \\
\hline 400 & & $T E-104-40$ \\
\hline 398 & & TE-104-38 \\
\hline 396 & & $T E-104-36$ \\
\hline
\end{tabular}


WHC-SD-WM-ATP-184

Revision 0

\subsubsection{Testing communication of TDS-AP-2 to each multiplexer}

\section{INFORMATION}

Procedures in this section serve to verify and validate the communication capabilities of TDS-AP-2 to each multiplexer by

shorting a selected thermocouple and verifying the response changed appropriately.

1.8.3.1 In 241-AP-271 use TDS-AP-2 to read the value of point 501 (TE-105-1). RECORD the reading.

1.8.3.2 At Tank AP-105, on multiplexer MUX-105-1: use the jumper to short the terminals the thermocouple in the previous step are attached.

1.8.3.3 VERIFY the reading changed.

1.8.3.4 Remove the jumper and VERIFY the reading is the same as the value of the prior reading \pm 2 degrees $F$ ( \pm 1 degrees $C$ ).

1.8.3.5 Repeat steps 1.8.3.1 through 1.8.3.4 inclusive for the following thermocouples (located at the following multiplexers):

\begin{tabular}{|c|c|c|c|}
\hline TDS-AP-2 Point No. & Tank No. & $\begin{array}{c}\text { Multiplexer } \\
\text { No. }\end{array}$ & $\begin{array}{c}\text { Thermocouple } \\
\text { No. }\end{array}$ \\
\hline 572 & AP-105 & MUX-105-2 & TE-105-72 \\
\hline 641 & AP-106 & MUX-106-1 & TE-106-21 \\
\hline 741 & AP-106 & MUX-106-2 & TE-106-94 \\
\hline 785 & AP-107 & MUX-107-1 & TE-107-45 \\
\hline 810 & AP-107 & MUX-107-2 & TE-107-70 \\
\hline 920 & AP-108 & MUX-108-1 & TE-108-60 \\
\hline 939 & AP-108 & MUX-108-2 & TE-108-79 \\
\hline
\end{tabular}

1.8.4 Compare TDS-AP-2 readings to MUX readings

1.8.4.1 In 241-AP-271 use TDS-AP-1 to read the value of points in the following table; RECORD the readings.

1.8.4.2 At each multiplexer use the type $E$ instrument to obtain the readings for the temperature elements listed in the following table; RECORD the readings. 
1.8.4.3 VERIFY the difference between readings made with the TDS-AP-2 and the field reading is Tess than 7 degrees $F$ (3.9 degrees C) for each thermocouple.

\begin{tabular}{|c|c|c|}
\hline TDS-AP-2 Point No. & Tank No. & $\begin{array}{c}\text { Thermocouple } \\
\text { No. }\end{array}$ \\
\hline 552 & \multirow[t]{6}{*}{ AP- 105} & TE-105-52 \\
\hline 546 & & TE-105-46 \\
\hline 542 & & $T E-105-42$ \\
\hline 540 & & TE-105-40 \\
\hline 538 & & $\mathrm{TE}-105-38$ \\
\hline 536 & & TE-105-36 \\
\hline 672 & \multirow[t]{6}{*}{$A P-106$} & TE-106-52 \\
\hline 666 & & $T E-106-46$ \\
\hline 662 & & TE-106-42 \\
\hline 660 & & TE-106-40 \\
\hline 658 & & TE-106-38 \\
\hline 656 & & TE-106-36 \\
\hline 792 & \multirow[t]{6}{*}{ AP-107 } & $\mathrm{TE}-107-52$ \\
\hline 786 & & $\mathrm{TE}-107-46$ \\
\hline 782 & & $\mathrm{TE}-107-42$ \\
\hline 780 & & $\mathrm{TE}-107-40$ \\
\hline 778 & & TE-107-38 \\
\hline 776 & & $\mathrm{TE}-107-36$ \\
\hline 912 & \multirow[t]{6}{*}{$A P-108$} & $T E-108-52$ \\
\hline 906 & & TE-108-46 \\
\hline 902 & & $T E-108-42$ \\
\hline 900 & & $T E-108-40$ \\
\hline 898 & & $\mathrm{TE}-108-38$ \\
\hline 896 & & $T E-108-36$ \\
\hline
\end{tabular}




\section{WHC-SD-WM-ATP-184}

Revision 0

\subsection{ACCEPTANCE TEST CLOSURE}

1.9.1 The person(s), by their signature below state the temperature displays TDS-AP-1, TDS-AP-2 and associated components (as configured) are functional and ready for use.

Test Director

AP Tank Farm Operations
Date

Date
Project Engineer Date 
WHC-SD-WM-ATP-184

Revision 0

\subsection{TEST DATA SHEETS}

The Test Data Sheets are used to document any procedure step requiring verification or recording of a value. All entries are made in black ink. A description of the data sheet format follows. Upon successful completion of testing activities, the master copy of the test execution data sheets shall be signed by the Test Witnesses. Witness signatures at the bottom of the data sheets indicate that the witness agrees to the accuracy of the data recorded and comparisons made.

1. Date of Test--Record the date the test is performed.

2. Procedure Step Number--This column contains the test steps requiring verification.

3. Item--This column contains the item or parameter being verified or recorded.

4. Expected Result--This column indicates the acceptable value of the item being recorded.

5. Value--Record the quantitative or qualitative measure (i.e., a line voltage may have a value of $120 \mathrm{~V}$, whereas a pump may have a value of $\mathrm{ON}$ or OFF) of the item being verified in this column.

6. Accept/Reject--Indicate whether the value obtained is acceptable in comparison with the Expected Value.

7. Comment--If the value is rejected, give a justification for denial.

8. QA--This column indicates that $Q A$ concurred with the items recorded or verified. Test Data Sheets are in Appendix A.

\subsection{TEST LOG SHEET}

Test Log Sheets are used to document test start and stop times and to document any other notes concerning the execution of the Acceptance Test Procedure. A Test Log Sheet is included in Appendix C. 
WHC-SD-WM-ATP-184

Revision 0

\subsection{DIGITAL DISPLAY UNIT: SELF TESTS PERFORMED AT POHER ON.}

The system executes multiple hardware tests at initial start-up. As each test is performed, the system displays a message to indicate the test currently in progress. If it passes the current test, a beep will sound and the system will automatically proceed to the next test. If the system fails the current test, an error message will display and an error beep will sound. Be aware, however, that certain test fallures are considered non-recoverable and will result in complete shut-down of the system. These fajlures require immediate repair before the recorder can continue power-up. For more information on non-recoverable failures, see the paragraph(s) below.

When hardware tests are complete, the system loads the user programmed database. The first step in the process is to load and check the Profile block. If the block is found defective, the user is given the option of having the system repair any bad data in the block. The next step is to load and check the user's programmed points. If a point is found defective, the system will automatically delete it from the load. Upon completion of the load, the system will briefly display an error message indicating that bad points were found.

Follow the instructions below to power-up the instrument. (See page 3-1 of Instruction Manual):

1. Press the chassis latch shown in Figure 3-1.

2. Open the swingout chassis.

3. Turn the instrument POWER ON/OFF Switch (Figure 3-2) to ON.

The following explains each test performed at initial start-up along with any possible error messages and recommended actions. Each message dispiays briefly as the system passes each test.

\section{Memory Test:}

Tests the main CPU temporary data memory. Fajlure of this test is considered non-recoverable and your unit must be repaired before operation can resume. If your system fails this test, the message RAM FAIL XXXX HALT will display. ("XXXX" specifies the address of the first failure).

\section{Software Test:}

Compares the current checksum value to the stored checksum value of the system program memory. If those values differ, the message CHKSUM FAIL, IGNORE? wil1 display. Failure of this test is considered non-recoverable and your unit must be repaired before operation can resume. The only time this message should be ignored is if you have just installed a system software update in you unit. Any other time a failure occurs, it indicated either damaged system software or bad nonvolatile memory. 


\section{Systems Test:}

This group of routines tests the functionality of critical system hardware. If all tests pass, the unit will proceed to LOAD PROFILE.

First, the system tests for a successful link between the CPU Wait-State Generator and the keyboard and display. If either of these wait-states fail, the system will briefly display the messages KBD WAIT OFF and/or DIS HAIT OFF respectively.

Next, the system verifies the system interrupt controller hardware. If this test fails, the message 8259 FAILURE, IGNORE will briefly display. Failure of this test is considered non-recoverable and your unit must be repaired before operation can resume. The only time this message should be ignored is for trouble-shooting purposes.

The next routine tests for the presence and functionality of the ADC system. If this test fails, the system will briefly display the message ADC INTERRUPT FAIL. Failure of this test is not considered non-recoverable, however, your unit will not measure live inputs. If the system fails this test, it will bypass the two thermistor tests and continue to power-up with the Printer and Interface Controller (P/I) test.

Next, the system verifies the functionality of the thermistors $(A, B, C$, and D) used for ambient temperature local compensation of thermocouple inputs. (If you are equipped with a 24-point recorder, only thermistors $A$ and $B$ will be checked.) If thermistor A or B fails, the message THERM X FAILED! will briefly display. If either any of these thermistors fail, all locally compensated thermocouple inputs will display as INVALID.

Finally, the system verifies the communication hardware between the main CPU and the printer system (PDC). If the 8255 chip on the Printer and Interface Controller (P/I) is defective, the message P/I COM PORT FAILED! will briefly display. If the First-in, First-out (FIF0) chip to the P/I is defective, the message P/I FIF0 FAILED! will briefly display. Neither of these failures is considered non-recoverable and your unit will continue to power-up after briefly displaying one or both of the above failure messages. If either of these tests fails, the printer will probably malfunction. However the point scanning and alarm monitoring will function properly. 


\section{Load Profile:}

Tests and loads all user-programmed parameters into memory. Two failure messages are possible:

If the transfer was unsuccessful and some or all of the database is now faulty, the message DB RAM FAIL IGNORE? will briefly display. If you press the YES key, the system will continue to power-up. However, the database may not be intact. If you press the NO key, the message SYSTEM HALT will display and the power-up sequence will abort.

If the system found bad parameters during the transfer of the profile block, the message PROFILE ERR, CORRECT? will brief1y display. If you press the YES key, the unit will perform a boundary analysis of all profile data values and set "out of range" values to safe defaults. The "correction" will not necessarily restore the data to the user's original selections. Instead, the correction process is intended to allow the system to continue the power-up sequence successfully. If you press the No key, a system "Tock-up" may occur due to erroneous data in the profile block.

Whether you choose to correct this error or ignore it, it is recommended that you run a profile log immediately upon completion of the power-up sequence. This new log should be compared to the user's on-file historical profile log. If there are any differences, correct them by re-programing those parameters and performing a learn.

\section{Load Program:}

This routine tests and loads all user-programmed points into memory. Two failure messages as possible:

If the transfer to RAM was unsuccessful and some or all of the database is now faulty, the message DB RAM FAIL, IGNORE? will briefly display. If you press the YES key, the system will cont inue to power-up. However, the database may not be intact. If you press the No key, the message SYSTEM HALT will display and the power-up sequence will abort.

If one or more points contain defective program parameters, the message BAD POINTS FOUND will display for only 3 seconds. Bad points are automatically deleted from the download and the system display will read COMMAND?. The following steps must be taken if this error occurs:

1. Run a program log.

2. Compare the program log to the historical program 70 .

3. Re-program lost points.

4. Perform a LEARN operation.

Repeated failures of this type indicate a problem with nonvolatile memory 


\subsection{CHANGE CONTROL AND EXCEPTIONS TO ACCEPTANCE TEST SECTION}

\subsection{ACCEPTANCE TEST PROCEDURE CHANGE CONTROL}

Testing is to be conducted in accordance with the steps and requirements specified in this procedure. Any required field changes must be per Sections $1.5 .1,1.5 .2$, and 1.5.4. Field changes shall also be recorded as a test exception.

\subsection{TEST EXECUTION}

The test procedures detailed in Sections 1.7 and 1.8 shall be performed in sequential steps starting with Section 1.7.1, except for fault recovery, as specified within the procedure. As required by Section 1.5.3, the Recorder wil1 "checkoff" every test step in the space provided on the Recorder's copy of the test procedure as each step is completed. Any step that requires a value recording or verification must also be recorded on the Test Data Sheet.

\subsubsection{Without Exception}

2.2.1.1 Check applicable space on the Test Execution Sheet (Appendix D) to show that the test procedure has been performed and no exceptions have been recorded.

2.2.1.2 Sign and date the Test Execution Sheet in the spaces provided.

2.2.1.3 Distribute requisite copies of test procedure.

\subsubsection{With Exception(s) Resolved}

2.2.2.1 Check applicable space on the Test Execution Sheet to show that the test procedure has been performed with exceptions recorded and resolved.

2.2.2.2 Sign and date the Test Execution Sheet in the spaces provided.

2.2.2.3 Distribute requisite copies of test procedure.

\subsubsection{With Exception(s) Outstanding}

2.2.3.1 Check applicable space on the Test Execution Sheet to show that the test procedure has been performed with exceptions recorded, some or all of which are presently outstanding, unresolved.

2.2.3.2 Sign and date the Test Execution Sheet in the spaces provided.

2.2.3.3 Distribute requisite copies of test procedure. 
WHC-SD-WM-ATP-184

Revision 0

\subsection{RECORDING AND RESOLVING EXCEPTIONS}

\subsection{GENERAL}

Exceptions to the test procedure are sequentially numbered and recorded on individual Exception Sheets. This enables case-by-case resolution, recording, approval, and distribution of each exception.

\subsection{RECORDING}

3.2.1 Number each exception sequentially as it occurs in the comments column on the Test Data Sheet, or in the body of the test procedure, as applicable, and also record it on a Test Exception Sheet.

3.2.2 Enter test function of objecting party (ie Project Engineer, Quality).

3.2.3 Enter problem encountered and/or planned action to resolve each exception when determined.

3.2.4 The initials of the Project Engineer and Quality witness affirm the description of the Test Exception is accurate and complete.

\subsection{RETEST/RESOLUTION}

3.3.1 Record the action taken to resolve each exception on the Test Exception Sheet. Action taken might not be the same as planned action.

3.3.2 When action taken results in an acceptable retest, sign and date Acceptable Retest section of the Test Exception Sheet.

3.3.3 When action taken does not involve an acceptable retest, mark the N/A block. Resolve exception per Section 3.4.

3.3.4 The signatures of the Test Director and Quality witness affirm the description of the Retest performance is accurate and complete. 


\subsection{APPROVAL AND ACCEPTANCE}

3.4.1 The Project Engineer and Quality representative provides final approval of exception by checking one of the following on the Test Exception Sheet:

- Retest Approved and Accepted: Applicable when Retest Execution and Acceptance section is completed.

- Exception Accepted-As-Is: Requires detailed explanation.

- Other: Requires detailed explanation.

3.4.2 The Project Engineer and Quality representative signs and dates the Test Exception Sheet and obtains other internal approval, if required.

\subsection{DISTRIBUTION}

Distribute requisite copies of completed Test Exception Sheets to the test participants. 
WHC-SD-WM-ATP-184

Revision 0

APPENDIX A TEST DATA SHEETS 


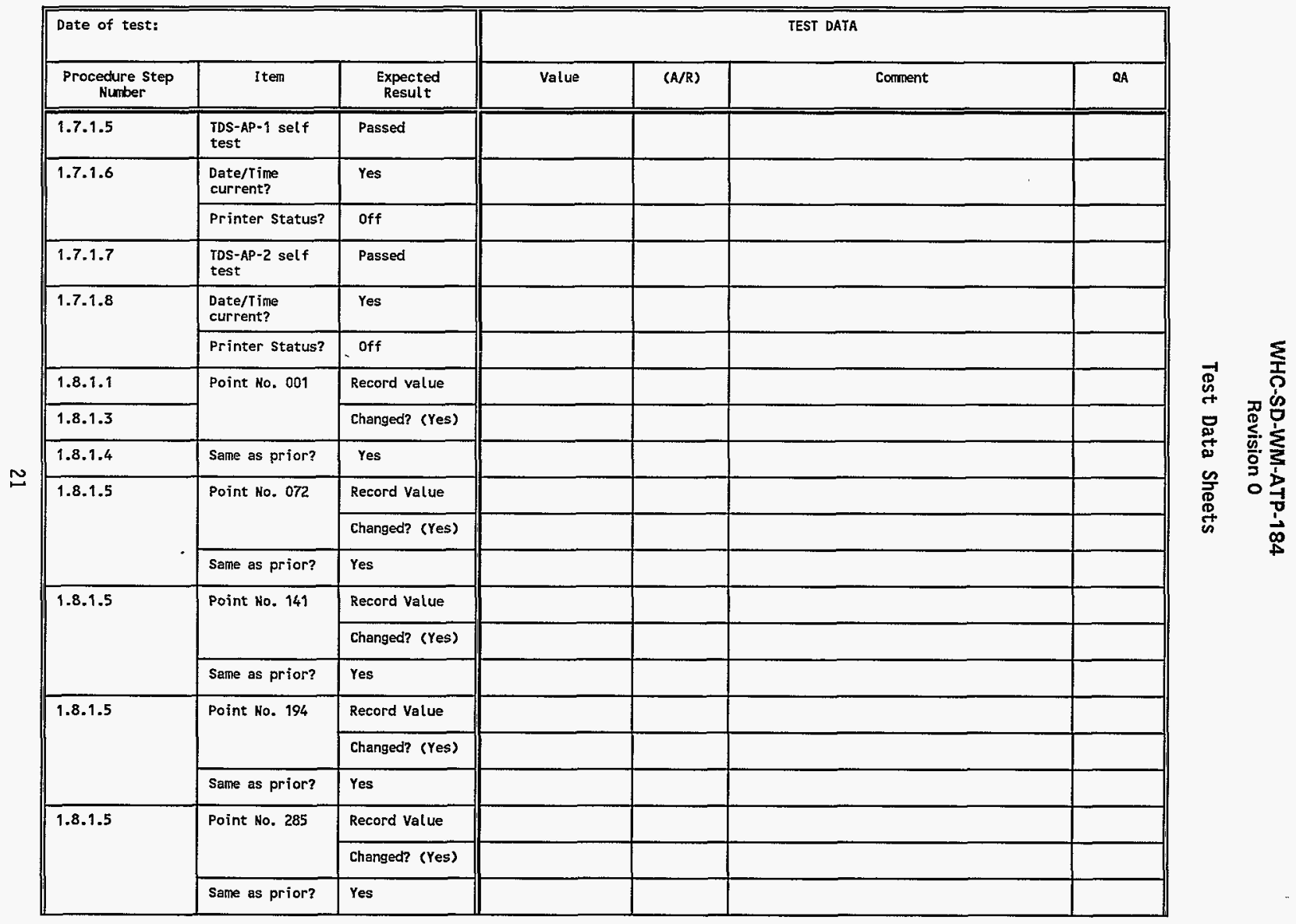




\begin{tabular}{|c|c|c|c|c|c|c|}
\hline \multicolumn{3}{|l|}{ Date of test: } & \multicolumn{4}{|c|}{ TEST DATA } \\
\hline $\begin{array}{c}\text { Procedure Step } \\
\text { Number }\end{array}$ & Item & $\begin{array}{c}\text { Expected } \\
\text { Result } t\end{array}$ & Value & $(A / R)$ & Comment & $Q A$ \\
\hline \multirow[t]{3}{*}{ 1.8.1.5 } & \multirow[t]{2}{*}{\begin{tabular}{|l} 
Point No. 310 \\
\end{tabular}} & Record Value & & & & \\
\hline & & Changed? (Yes) & & & & \\
\hline & Same as prior? & Yes & & & & \\
\hline \multirow[t]{3}{*}{ 1.8.1.5 } & \multirow[t]{2}{*}{ Point No. 420} & Record Value & & & & \\
\hline & & Changed? (Yes) & & & & \\
\hline & Same as prior? & Yes & & & & \\
\hline \multirow[t]{3}{*}{ 1.8.1.5 } & \multirow[t]{2}{*}{\begin{tabular}{|l} 
Point Ho. 439 \\
\end{tabular}} & Record Value & & & & \\
\hline & & Changed? (Yes) & & & & \\
\hline & Sane as prior? & Yes & & & & \\
\hline \multirow[t]{2}{*}{ 1.8.2.1 } & Inst. Cal. Ho. & Record Value & & & & \\
\hline & \begin{tabular}{|l|} 
Expiration Date \\
\end{tabular} & Record Value & & & & \\
\hline \multirow{3}{*}{$\begin{array}{l}1.8 .2 .2 \\
1.8 .2 .3 \\
1.8 .2 .4\end{array}$} & \multirow[t]{2}{*}{ Point No. 052} & 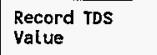 & & & & \\
\hline & & $\begin{array}{l}\text { Record MUX } \\
\text { Value }\end{array}$ & & & & \\
\hline & Diff $\leq 7$ deg $F ?$ & Yes & & & & \\
\hline \multirow{3}{*}{$\begin{array}{r}1.8 .2 .2 \\
1.8 .2 .3 \\
1.8 .2 .4\end{array}$} & \multirow[t]{2}{*}{ Point Ho. 046} & \begin{tabular}{|l|}
$\begin{array}{l}\text { Record TDS } \\
\text { Value }\end{array}$ \\
\end{tabular} & & & & \\
\hline & & $\begin{array}{l}\text { Record MUX } \\
\text { Value }\end{array}$ & & & & \\
\hline & Diff $\leq 7$ deg f? & res & & & & \\
\hline \multirow{3}{*}{$\begin{array}{l}1.8 .2 .2 \\
1.8 .2 .3 \\
1.8 .2 .4\end{array}$} & \multirow[t]{2}{*}{\begin{tabular}{|l|} 
Point Ko. 042 \\
\end{tabular}} & \begin{tabular}{|l|}
$\begin{array}{l}\text { Record TDS } \\
\text { Value }\end{array}$ \\
\end{tabular} & & & & \\
\hline & & $\begin{array}{l}\begin{array}{l}\text { Record Mux } \\
\text { Value }\end{array} \\
\text { alus }\end{array}$ & & & & \\
\hline & Diff $\leq 7$ deg F? & Yes & & & & \\
\hline
\end{tabular}




\begin{tabular}{|c|c|c|c|c|c|c|}
\hline \multicolumn{3}{|l|}{ Date of test: } & \multicolumn{4}{|c|}{ TEST DATA } \\
\hline $\begin{array}{l}\text { Procedure Step } \\
\text { Number }\end{array}$ & I tem & $\begin{array}{l}\text { Expected } \\
\text { Result }\end{array}$ & Value & $(A / R)$ & Comment & $O A$ \\
\hline \multirow{3}{*}{$\begin{array}{l}1.8 .2 .2 \\
1.8 .2 .3 \\
1.8 .2 .4\end{array}$} & \multirow[t]{2}{*}{ Point No. 040} & $\begin{array}{l}\text { Record TDS } \\
\text { Value }\end{array}$ & & & & \\
\hline & & $\begin{array}{l}\text { Record MuX } \\
\text { Value }\end{array}$ & & & & \\
\hline & Diff $\leq 7$ deg F? & Yes & & & & \\
\hline \multirow{3}{*}{$\begin{array}{l}1.8 .2 .2 .2 \\
1.88 .23 \\
1.8 .22 .4\end{array}$} & \multirow[t]{2}{*}{ Point No. 038} & \begin{tabular}{|l} 
Record TDS \\
Value
\end{tabular} & & & & \\
\hline & & $\begin{array}{l}\text { Record MUX } \\
\text { Value }\end{array}$ & & & & \\
\hline & Diff $\leq 7$ deg F? & Yes & & & & \\
\hline \multirow{3}{*}{$\begin{array}{l}1.8 .2 .2 \\
1.8 .2 .3 \\
1.8 .2 .4\end{array}$} & \multirow[t]{2}{*}{ Point No. 036} & \begin{tabular}{|l}
$\begin{array}{l}\text { Record TDS } \\
\text { Value }\end{array}$ \\
\end{tabular} & & & & \\
\hline & & \begin{tabular}{|l} 
Record MUX \\
Value
\end{tabular} & & & & \\
\hline & Diff $\leq 7$ deg $F ?$ & Yes & & & & \\
\hline \multirow{3}{*}{$\begin{array}{l}1.8 .2 .2 \\
1.8 .2 .3 \\
1.8 .2 .4\end{array}$} & \multirow[t]{2}{*}{ Point No. 172} & \begin{tabular}{|l|}
$\begin{array}{l}\text { Record TDS } \\
\text { Value }\end{array}$ \\
\end{tabular} & & & & \\
\hline & & $\begin{array}{l}\text { Record MUX } \\
\text { Value }\end{array}$ & & & & \\
\hline & Diff $\leq 7$ deg F? & Yes & & & & \\
\hline \multirow{3}{*}{$\begin{array}{l}1.8 .2 .2 \\
1.8 .2 .3 \\
1.8 .2 .4\end{array}$} & \multirow[t]{2}{*}{ Point No. 166} & $\begin{array}{l}\text { Record TDS } \\
\text { Value }\end{array}$ & & & & \\
\hline & & $\begin{array}{l}\text { Record MUX } \\
\text { Value }\end{array}$ & & & & \\
\hline & Diff $\leq 7 \mathrm{deg} F ?$ & Yes & & & & \\
\hline \multirow{3}{*}{$\begin{array}{l}1.8 .2 .2 \\
1.8 .2 .3 \\
1.8 .2 .4\end{array}$} & \multirow[t]{2}{*}{ Point No. 162} & \begin{tabular}{|l} 
Record ros \\
Value
\end{tabular} & & & & \\
\hline & & $\begin{array}{l}\begin{array}{l}\text { Record MuX } \\
\text { Value }\end{array} \\
\end{array}$ & & & & \\
\hline & Diff $\leq 7$ deg F? & Yes & & & & \\
\hline
\end{tabular}




\begin{tabular}{|c|c|c|c|c|c|c|}
\hline \multicolumn{3}{|l|}{ Date of test: } & \multicolumn{4}{|c|}{ IEST DATA } \\
\hline $\begin{array}{c}\text { Procedure Step } \\
\text { Number }\end{array}$ & Item & $\begin{array}{l}\text { Expected } \\
\text { Result t }\end{array}$ & Value & $(A / R)$ & Comnent & QA \\
\hline \multirow{3}{*}{$\begin{array}{l}1.8 .2 .2 \\
1.8 .2 .3 \\
1.8 .2 .4\end{array}$} & \multirow[t]{2}{*}{ Point Mo. 160} & $\begin{array}{l}\text { Record TDS } \\
\text { Value }\end{array}$ & & & & \\
\hline & & $\begin{array}{l}\text { Record MUX } \\
\text { Value }\end{array}$ & & & & \\
\hline & Diff $\leq 7$ deg $F$ ? & Yes & & & & \\
\hline \multirow{3}{*}{$\begin{array}{l}1.8 .2 .2 \\
1.8 .2 .3 \\
1.8 .2 .4\end{array}$} & \multirow[t]{2}{*}{ Point Ho. 158} & $\begin{array}{l}\text { Record TDS } \\
\text { Value }\end{array}$ & & & & \\
\hline & & $\begin{array}{l}\text { Record MUX } \\
\text { Value }\end{array}$ & & & & \\
\hline & Diff $\leq 7$ deg F? & Yes & & & & \\
\hline \multirow{3}{*}{$\begin{array}{l}1.8 .2 .2 \\
1.882 .3 \\
1.8 .2 .4\end{array}$} & \multirow[t]{2}{*}{ Point No. 156} & $\begin{array}{l}\text { Record tDS } \\
\text { Value }\end{array}$ & & & & \\
\hline & & $\begin{array}{l}\text { Record MUX } \\
\text { Value }\end{array}$ & & & & \\
\hline & Diff $\leq 7$ deg $F ?$ & Yes & & & & \\
\hline \multirow{3}{*}{$\begin{array}{l}1.8 .2 .2 \\
1.8 .2 .3 \\
1.8 .2 .4\end{array}$} & \multirow[t]{2}{*}{ Point No. 290} & $\begin{array}{l}\text { Record TDS } \\
\text { Value }\end{array}$ & & & & \\
\hline & & $\begin{array}{l}\text { Record MUX } \\
\text { Value }\end{array}$ & & & & \\
\hline & $D i f f \leq 7 \operatorname{deg} F ?$ & Yes & & & & \\
\hline \multirow{3}{*}{$\begin{array}{l}1.8 .2 .2 \\
1.8 .2 .3 \\
1.8 .2 .4\end{array}$} & \multirow[t]{2}{*}{ Point No. 286} & $\begin{array}{l}\text { Record TDS } \\
\text { Value }\end{array}$ & & & & \\
\hline & & $\begin{array}{l}\text { Record MUX } \\
\text { Value }\end{array}$ & & & & \\
\hline & Diff $\leq 7$ deg F? & Yes & & & & \\
\hline \multirow{3}{*}{$\begin{array}{l}1.8 .2 .2 \\
1.8 .2 .3 \\
1.8 .2 .4\end{array}$} & \multirow[t]{2}{*}{\begin{tabular}{|l} 
Point No. 282 \\
\end{tabular}} & $\begin{array}{l}\begin{array}{l}\text { Record TDS } \\
\text { Value }\end{array} \\
\end{array}$ & & & & \\
\hline & & $\begin{array}{l}\text { Record MUX } \\
\text { Value }\end{array}$ & & & & \\
\hline & $D i f f \leq 7$ deg F? & Yes & & & & \\
\hline
\end{tabular}




\begin{tabular}{|c|c|c|c|c|c|c|}
\hline \multicolumn{3}{|l|}{ Date of test: } & \multicolumn{4}{|c|}{ TEST DATA } \\
\hline $\begin{array}{c}\text { Procedure Step } \\
\text { Number }\end{array}$ & Item & $\begin{array}{c}\text { Expected } \\
\text { Resul t }\end{array}$ & Value & $(A / R)$ & Comment & QA \\
\hline \multirow[t]{3}{*}{$\begin{array}{l}1.8 .2 .2 \\
1.8 .2 .3 \\
1.8 .2 .4\end{array}$} & \multirow[t]{2}{*}{ Point Ho. 280} & \begin{tabular}{|l}
$\begin{array}{l}\text { Record TDS } \\
\text { Value }\end{array}$ \\
\end{tabular} & & & & \\
\hline & & $\begin{array}{l}\text { Record MUX } \\
\text { Value }\end{array}$ & & & & \\
\hline & Diff $\leq 7 \mathrm{deg} F ?$ & Yes & & & & \\
\hline \multirow{3}{*}{$\begin{array}{l}1.8 .2 .22 \\
1.882 .3 \\
1.8 .2 .4\end{array}$} & \multirow[t]{2}{*}{ Point No. 278} & $\begin{array}{l}\text { Record TDS } \\
\text { Value }\end{array}$ & & & & \\
\hline & & $\begin{array}{l}\text { Record MUX } \\
\text { Value }\end{array}$ & & & & \\
\hline & Diff $\leq 7$ deg F? & Yes & & & & \\
\hline \multirow{3}{*}{$\begin{array}{l}1.8 .2 .2 \\
1.8 .2 .3 \\
1.8 .2 .4\end{array}$} & \multirow[t]{2}{*}{ Point No. 276} & $\begin{array}{l}\text { Record TDS } \\
\text { Value }\end{array}$ & & & & \\
\hline & & \begin{tabular}{|l} 
Record MUX \\
Value
\end{tabular} & & & & \\
\hline & Diff $\leq 7$ deg $F ?$ & Yes & & & & \\
\hline \multirow[t]{3}{*}{$\begin{array}{l}1.8 .2 .2 \\
1.8 .2 .3 \\
1.8 .2 .4\end{array}$} & \multirow[t]{2}{*}{ Point No. 412} & \begin{tabular}{|l}
$\begin{array}{l}\text { Record TDS } \\
\text { Value }\end{array}$ \\
\end{tabular} & & & & \\
\hline & & \begin{tabular}{|l}
$\begin{array}{l}\text { Record MUX } \\
\text { Value }\end{array}$ \\
\end{tabular} & & & & \\
\hline & Diff $\leq 7$ deg F? & Yes & & & & \\
\hline \multirow[t]{3}{*}{$\begin{array}{l}1.8 .2 .2 \\
1.8 .2 .3 \\
1.8 .2 .4\end{array}$} & \multirow[t]{2}{*}{ Point Ho. 406} & \begin{tabular}{|l|l|}
$\begin{array}{l}\text { Record TOS } \\
\text { Value }\end{array}$ \\
\end{tabular} & & & & \\
\hline & & \begin{tabular}{|l}
$\begin{array}{l}\text { Record MUX } \\
\text { Value }\end{array}$ \\
\end{tabular} & & & & \\
\hline & Diff $\leq 7$ deg F? & Yes & & & & \\
\hline \multirow{3}{*}{$\begin{array}{l}1.8 .2 .2 \\
1.8 .2 .3 \\
1.8 .2 .4\end{array}$} & \multirow[t]{2}{*}{ Point No. 402} & \begin{tabular}{|l}
$\begin{array}{l}\text { Record TDS } \\
\text { Value }\end{array}$ \\
\end{tabular} & & & & \\
\hline & & \begin{tabular}{|l}
$\begin{array}{l}\text { Record MUX } \\
\text { Value }\end{array}$ \\
\end{tabular} & & & & \\
\hline & $D i f f \leq 7$ deg F? & Yes & & & & \\
\hline
\end{tabular}




\begin{tabular}{|c|c|c|c|c|c|c|}
\hline \multicolumn{3}{|l|}{ Date of test: } & \multicolumn{4}{|c|}{ TEST DATA } \\
\hline $\begin{array}{c}\text { Procedure Step } \\
\text { Number }\end{array}$ & Iten & $\begin{array}{c}\text { Expected } \\
\text { Result }\end{array}$ & Value & $(A / R)$ & Comment & $\mathrm{aA}$ \\
\hline \multirow{3}{*}{$\begin{array}{l}1.8 .2 .2 \\
1.8 .2 .3 \\
1.8 .2 .4\end{array}$} & \multirow[t]{2}{*}{ Point No. 400} & $\begin{array}{l}\text { Record TDS } \\
\text { Value }\end{array}$ & & & & \\
\hline & & $\begin{array}{l}\text { Record MUX } \\
\text { Value }\end{array}$ & & & & \\
\hline & Diff $\leq 7$ deg $F$ ? & Yes & & & & \\
\hline \multirow[t]{3}{*}{$\begin{array}{l}1.8 .2 .2 \\
1.8 .2 .3 \\
1.8 .2 .4\end{array}$} & \multirow[t]{2}{*}{ Point No. 398} & $\begin{array}{l}\text { Record TDS } \\
\text { Value } \\
\end{array}$ & & & & \\
\hline & & $\begin{array}{l}\text { Record MUX } \\
\text { Value }\end{array}$ & & & & \\
\hline & Diff $\leq 7$ deg F? & Yes & & & & \\
\hline \multirow{3}{*}{$\begin{array}{l}1.8 .2 .2 \\
1.8 .2 .3 \\
1.8 .2 .4\end{array}$} & \multirow[t]{2}{*}{ Point No. 396} & $\begin{array}{l}\text { Record TDS } \\
\text { Value }\end{array}$ & & & & \\
\hline & & $\begin{array}{l}\text { Record MUX } \\
\text { Value }\end{array}$ & & & & \\
\hline & Diff $\leq 7$ deg $F ?$ & Yes & & & & \\
\hline 1.8 .3 .1 & \multirow[t]{2}{*}{ Point No. 501} & Record Value & & & & \\
\hline 1.8 .3 .3 & & Changed? (Yes) & & & & \\
\hline 1.8.3.4 & Same as prior? & Yes & & & & \\
\hline \multirow[t]{3}{*}{1.8 .3 .5} & \multirow[t]{2}{*}{ Point No. 572} & Record value & & & & \\
\hline & & Changed? (Yes) & & & & \\
\hline & Same as prior? & Yes & & & & \\
\hline \multirow[t]{3}{*}{1.8 .3 .5} & \multirow[t]{2}{*}{ Point No. 641} & Record value & & & & \\
\hline & & Changed? (Yes) & & & & \\
\hline & Seme as prior? & Yes & & & & \\
\hline
\end{tabular}




\begin{tabular}{|c|c|c|c|c|c|c|}
\hline \multicolumn{3}{|l|}{ Date of test: } & \multicolumn{4}{|c|}{ TEST DATA } \\
\hline $\begin{array}{l}\text { Procedure Step } \\
\text { Munber }\end{array}$ & Item & $\begin{array}{l}\text { Expected } \\
\text { Result }\end{array}$ & Value & $(A / R)$ & Corment & $Q A$ \\
\hline \multirow[t]{3}{*}{1.8 .3 .5} & \multirow[t]{2}{*}{ Point Ho. 741} & Record Value & & & & \\
\hline & & Changed? (Yes) & & & & \\
\hline & Same as prior? & Yes & & & & \\
\hline \multirow[t]{3}{*}{ 1.8.3.5 } & \multirow[t]{2}{*}{ Point No. 785} & Record Value & & & & \\
\hline & & Changed? (Yes) & & & & \\
\hline & Same as prior? & Yes & & & & \\
\hline \multirow[t]{3}{*}{ 1.8.3.5 } & \multirow[t]{2}{*}{ Point Ho. $\mathbf{8 1 0}$} & Record Value & & & & \\
\hline & & Changed? (Yes) & & & & \\
\hline & Same as prior? & Yes & & & & \\
\hline \multirow[t]{3}{*}{ 1.8.3.5 } & \multirow[t]{2}{*}{ Point Ho. 920} & Record Value & & & & \\
\hline & & changed? (Yes) & & & & \\
\hline & Seme as prior? & Yes & & & & \\
\hline \multirow[t]{3}{*}{ 1.8.3.5 } & \multirow[t]{2}{*}{ Point Ho. 939} & Record Value & & & & \\
\hline & & changed? (Yes) & & & & \\
\hline & Same as prior? & Yes & & & & \\
\hline \multirow{3}{*}{$\begin{array}{l}1.8 .4 .1 \\
1.8 .4 .2 \\
1.8 .4 .3\end{array}$} & \multirow[t]{2}{*}{ Point No. 552} & $\begin{array}{l}\text { Record TDS } \\
\text { Value }\end{array}$ & & & & \\
\hline & & $\begin{array}{l}\text { Record MuX } \\
\text { Value }\end{array}$ & & & & \\
\hline & Diff $\leq 7$ deg $F ?$ & Yes & & & & \\
\hline \multirow{3}{*}{$\begin{array}{l}1.8 .4 .1 \\
1.8 .4 .2 \\
1.8 .4 .3\end{array}$} & \multirow[t]{2}{*}{ Point No. 546} & $\begin{array}{l}\text { Record TOS } \\
\text { Value }\end{array}$ & & & & \\
\hline & & $\begin{array}{l}\text { Record MUX } \\
\text { Value }\end{array}$ & & & & \\
\hline & Diff $\leq 7$ deg $F ?$ & Yes & & & & \\
\hline
\end{tabular}




\begin{tabular}{|c|c|c|c|c|c|c|}
\hline \multicolumn{3}{|l|}{ Date of test: } & \multicolumn{4}{|c|}{ TEST DATA } \\
\hline $\begin{array}{c}\text { Procedure Step } \\
\text { Number }\end{array}$ & Item & $\begin{array}{c}\text { Expected } \\
\text { Result }\end{array}$ & Value & $(A / R)$ & Corment & AA \\
\hline \multirow{3}{*}{$\begin{array}{l}1.8 .4 .1 \\
1.8 .4 .2 \\
1.8 .4 .3\end{array}$} & \multirow[t]{2}{*}{ Point No. 542} & $\begin{array}{l}\text { Record TDS } \\
\text { Value }\end{array}$ & & & & \\
\hline & & $\begin{array}{l}\text { Record MUX } \\
\text { Value }\end{array}$ & & & & \\
\hline & Diff $\leq 7$ deg F? & res & & & & \\
\hline \multirow{3}{*}{$\begin{array}{l}1.8 .4 .1 \\
1.8 .4 .2 \\
1.8 .4 .3\end{array}$} & \multirow[t]{2}{*}{ Point Ho. 540} & $\begin{array}{l}\text { Record TDS } \\
\text { Value }\end{array}$ & & & & \\
\hline & & $\begin{array}{l}\text { Record MUX } \\
\text { Value }\end{array}$ & & & & \\
\hline & Diff $\leq 7$ deg $F ?$ & Yes & & & & \\
\hline \multirow{3}{*}{$\begin{array}{l}1.8 .4 .1 \\
1.8 .4 .2 \\
1.8 .4 .3\end{array}$} & \multirow[t]{2}{*}{ Point No. 538} & $\begin{array}{l}\begin{array}{l}\text { Record TDS } \\
\text { Value }\end{array} \\
\end{array}$ & & & & \\
\hline & & $\begin{array}{l}\text { Record MUX } \\
\text { Value }\end{array}$ & & & & \\
\hline & Diff $\leq 7$ deg F? & Yes & & & & \\
\hline \multirow{3}{*}{$\begin{array}{l}1.8 .4 .1 \\
1.8 .4 .2 \\
1.8 .4 .3\end{array}$} & \multirow[t]{2}{*}{ Point No. 536} & $\begin{array}{l}\text { Record TDS } \\
\text { Value }\end{array}$ & & & & \\
\hline & & $\begin{array}{l}\text { Record MUX } \\
\text { Value }\end{array}$ & & & & \\
\hline & Diff $\leq 7$ deg $F ?$ & Yes & & & & \\
\hline \multirow{3}{*}{$\begin{array}{l}1.8 .4 .1 \\
1.8 .4 .2 \\
1.8 .4 .3\end{array}$} & \multirow[t]{2}{*}{ Point No. 672} & $\begin{array}{l}\text { Record TDS } \\
\text { Value }\end{array}$ & & & & \\
\hline & & $\begin{array}{l}\text { Record MUX } \\
\text { Value }\end{array}$ & & & & \\
\hline & Diff $\leq 7$ deg $F ?$ & Yes & & & & \\
\hline \multirow{3}{*}{$\begin{array}{l}1.8 .4 .1 \\
1.8 .4 .2 \\
1.8 .4 .3\end{array}$} & \multirow[t]{2}{*}{ Point No. 666} & $\begin{array}{l}\text { Record TDS } \\
\text { Value }\end{array}$ & & & & \\
\hline & & $\begin{array}{l}\text { Record MUX } \\
\text { Value }\end{array}$ & & & & \\
\hline & Diff $\leq 7$ deg $\mathrm{F} ?$ & Yes & & & & \\
\hline
\end{tabular}




\begin{tabular}{|c|c|c|c|c|c|c|}
\hline \multicolumn{3}{|l|}{ Date of test: } & \multicolumn{4}{|c|}{ TEST DATA } \\
\hline $\begin{array}{l}\text { Procedure Step } \\
\text { Number }\end{array}$ & Item & $\begin{array}{c}\text { Expected } \\
\text { Result }\end{array}$ & value & (A/R) & Comment & $\overline{O A}$ \\
\hline \multirow{3}{*}{$\begin{array}{l}1.8 .4 .1 \\
1.8 .8 .2 \\
1.8 .4 .3\end{array}$} & \multirow[t]{2}{*}{ Point No. 662} & $\begin{array}{l}\text { Record TDS } \\
\text { Value }\end{array}$ & & & & \\
\hline & & $\begin{array}{l}\text { Record MUX } \\
\text { Value }\end{array}$ & & & & \\
\hline & Diff $\leq 7 \mathrm{deg} F ?$ & Yes & & & & \\
\hline \multirow{3}{*}{$\begin{array}{l}1.8 .4 .1 \\
1.8 .4 .2 \\
1.8 .4 .3\end{array}$} & \multirow[t]{2}{*}{ Point No. 660} & $\begin{array}{l}\text { Record TDS } \\
\text { Value }\end{array}$ & & & & \\
\hline & & $\begin{array}{l}\text { Record MUX } \\
\text { Value }\end{array}$ & & & & \\
\hline & Diff $\leq 7$ deg F? & Yes & & & & \\
\hline \multirow{3}{*}{$\begin{array}{l}1.8 .4 .1 \\
1.8 .4 .2 \\
1.8 .4 .3\end{array}$} & \multirow[t]{2}{*}{ Point No. 658} & $\begin{array}{l}\text { Record TDS } \\
\text { Value }\end{array}$ & & & & \\
\hline & & $\begin{array}{l}\text { Record Nux } \\
\text { Value }\end{array}$ & & & & \\
\hline & Diff $\leq 7$ deg $F ?$ & Yes & & & & \\
\hline \multirow{3}{*}{$\begin{array}{l}1.8 .4 .1 \\
1.8 .4 .2 \\
1.8 .4 .3\end{array}$} & \multirow[t]{2}{*}{ Point Ho. 656} & $\begin{array}{l}\text { Record TDS } \\
\text { Value }\end{array}$ & & & & \\
\hline & & $\begin{array}{l}\text { Record MUX } \\
\text { Value }\end{array}$ & & & & \\
\hline & Diff $\leq 7 \mathrm{deg} F ?$ & Yes & & & & \\
\hline \multirow{3}{*}{$\begin{array}{l}1.8 .4 .1 \\
1.8 .4 .2 \\
1.8 .4 .3\end{array}$} & \multirow[t]{2}{*}{ Point No. 792} & $\begin{array}{l}\text { Record TDS } \\
\text { Value }\end{array}$ & & & & \\
\hline & & $\begin{array}{l}\text { Record MUX } \\
\text { Value }\end{array}$ & & & & \\
\hline & Diff $\leq 7 \mathrm{dg} F ?$ & Yes & & & & \\
\hline \multirow{3}{*}{$\begin{array}{l}1.8 .4 .1 \\
1.8 .4 .2 \\
1.8 .4 .3\end{array}$} & \multirow[t]{2}{*}{ Point No. 786} & $\begin{array}{l}\text { Record TOS } \\
\text { Value }\end{array}$ & & & & \\
\hline & & $\begin{array}{l}\text { Record MUX } \\
\text { Value }\end{array}$ & & & & \\
\hline & Diff $\leq 7$ deg F? & Yes & & & & \\
\hline
\end{tabular}




\begin{tabular}{|c|c|c|c|c|c|c|}
\hline \multicolumn{3}{|l|}{ Date of test: } & \multicolumn{4}{|c|}{ TEST DATA } \\
\hline $\begin{array}{c}\text { Procedure Step } \\
\text { Nunber }\end{array}$ & Iten & $\begin{array}{l}\text { Expected } \\
\text { Result }\end{array}$ & value & (A/R) & Comment & $\overline{Q A}$ \\
\hline \multirow{3}{*}{$\begin{array}{l}1.8 .4 .1 \\
1.8 .4 .2 \\
1.8 .4 .3\end{array}$} & \multirow[t]{2}{*}{ Point No. 782} & $\begin{array}{l}\text { Record TDS } \\
\text { Value }\end{array}$ & & & & \\
\hline & & $\begin{array}{l}\begin{array}{l}\text { Record MUX } \\
\text { Value }\end{array} \\
\text { alo }\end{array}$ & & & & \\
\hline & Diff $\leq 7 \mathrm{deg} F ?$ & Yes & & & & \\
\hline \multirow{3}{*}{$\begin{array}{l}1.8 .4 .1 \\
1.8 .4 .2 \\
1.8 .4 .3\end{array}$} & \multirow[t]{2}{*}{ Point No. 780} & $\begin{array}{l}\text { Record TDS } \\
\text { Value }\end{array}$ & & & & \\
\hline & & $\begin{array}{l}\text { Record MUX } \\
\text { Value }\end{array}$ & & & & \\
\hline & Diff $\leq 7$ deg $F ?$ & Yes & & & & \\
\hline \multirow{3}{*}{$\begin{array}{l}1.8 .4 .1 \\
1.8 .84 .2 \\
1.8 .4 .3\end{array}$} & \multirow[t]{2}{*}{ Point No. 778} & $\begin{array}{l}\text { Record TDS } \\
\text { Value }\end{array}$ & & & & \\
\hline & & $\begin{array}{l}\text { Record MUX } \\
\text { Value }\end{array}$ & & & & \\
\hline & Diff $\leq 7$ deg F? & Yes & & & & \\
\hline \multirow[t]{3}{*}{$\begin{array}{l}1.8 .4 .1 \\
1.8 .4 .2 \\
1.8 .4 .3\end{array}$} & \multirow[t]{2}{*}{ Point Ho. 776} & $\begin{array}{l}\text { Record TDS } \\
\text { Value }\end{array}$ & & & & \\
\hline & & $\begin{array}{l}\text { Record MUX } \\
\text { value }\end{array}$ & & & & \\
\hline & Diff $\leq 7$ deg $F ?$ & Yes & & & & \\
\hline \multirow{3}{*}{$\begin{array}{l}1.8 .4 .1 \\
1.8 .4 .2 \\
1.8 .4 .3\end{array}$} & \multirow[t]{2}{*}{ Point No. 912} & $\begin{array}{l}\text { Record yos } \\
\text { Value }\end{array}$ & & & & \\
\hline & & $\begin{array}{l}\text { Record MUX } \\
\text { Value }\end{array}$ & & & & \\
\hline & Diff $\leq 7$ deg F? & Yes & & & & \\
\hline \multirow{3}{*}{$\begin{array}{l}1.8 .4 .1 \\
1.8 .4 .2 \\
1.8 .4 .3\end{array}$} & \multirow[t]{2}{*}{ Point Ko. 906} & $\begin{array}{l}\text { Record TDS } \\
\text { Value }\end{array}$ & & & & \\
\hline & & $\begin{array}{l}\text { Record vuX } \\
\text { Value }\end{array}$ & & & & \\
\hline & $D$ iff $\leq 7 \operatorname{deg} F ?$ & Yes & & & & \\
\hline
\end{tabular}


WHC-SD-WM-ATP-184

Revision 0

Test Data Sheets

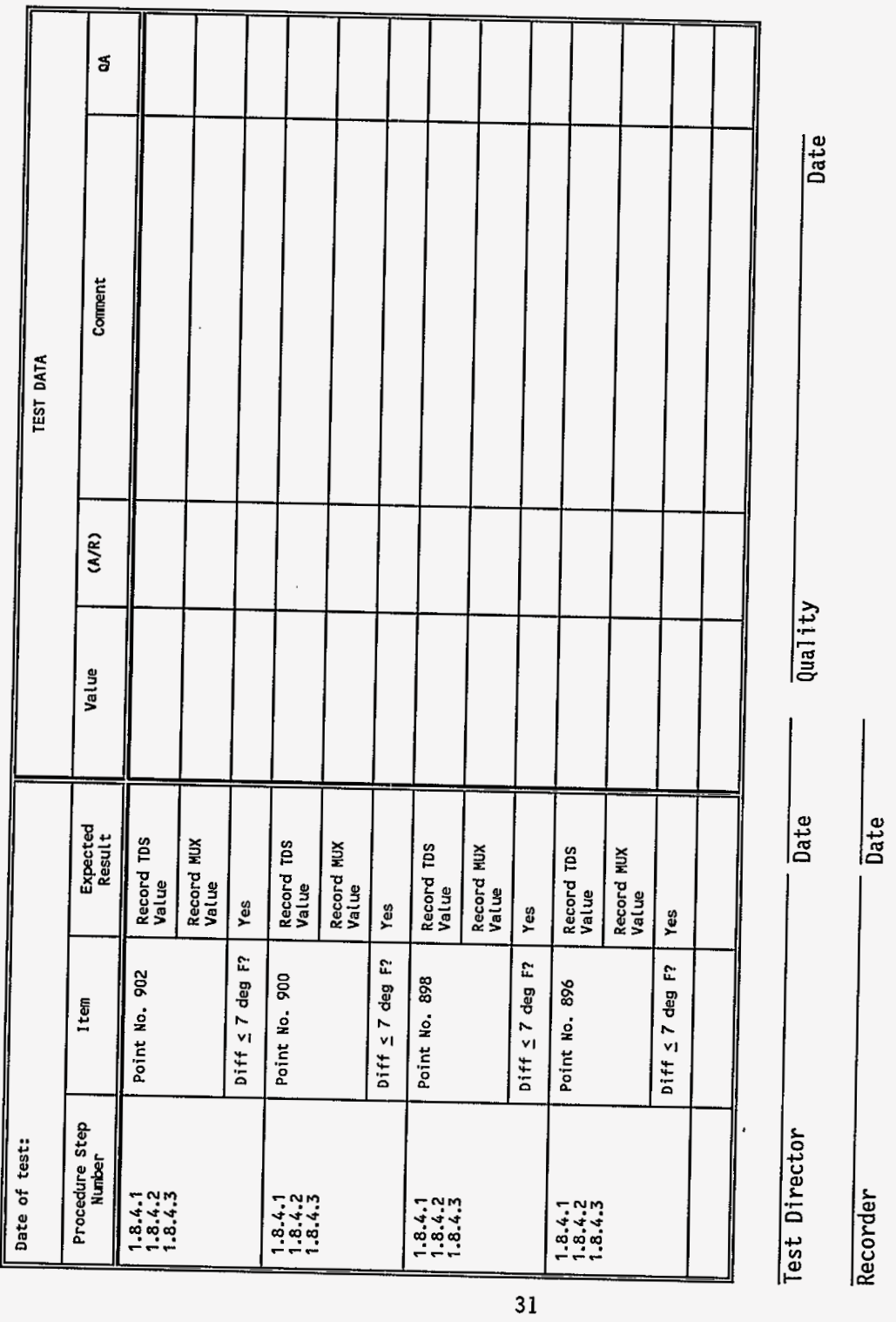


WHC-SD-WM-ATP- 184

Revision 0

APPENDIX B TEST EXCEPTION SHEET

(Copy as needed) 
WHC-SD-WM-ATP-184

Revision 0

TEST EXCEPTION \#

\begin{tabular}{|c|c|c|c|}
\hline \multicolumn{4}{|c|}{ Test Title: WHC-SD-WH-ATP-184, REV 0} \\
\hline \multicolumn{2}{|c|}{ EXCEPTIONS } & & \\
\hline \multirow{2}{*}{$\begin{array}{l}\text { Procedure } \\
\text { Step Mumber }\end{array}$} & \multirow[t]{2}{*}{ Description } & \multicolumn{2}{|c|}{ Initials/Date } \\
\hline & & $\begin{array}{l}\text { Project } \\
\text { Engineer }\end{array}$ & Quality \\
\hline & & & \\
\hline & & & \\
\hline & & & \\
\hline & & & \\
\hline & & & \\
\hline & & & \\
\hline & & & \\
\hline & & & \\
\hline
\end{tabular}

OBJECTING PARTY Date

ACCEPTABLE RETEST PERFORMED: YES NO

$N / A$

Quality

Date

Test Director

Date

Retest Approved and Accepted

Exception Accepted As Is

other

Explanation

EXCEPTION RESOLVED:

Yes

Project Engineer

Date

Yes, deferred

to Test Exception \#

Quality

Date

No 
WHC-SD-WM-ATP-184

Revision 0

APPENDIX C TEST LOG SHEET

(Copy as needed) 
WHC-SD-WM-ATP-184

Revision 0

TEST LOG: WHC-SD-WM-ATP-184, REV 0

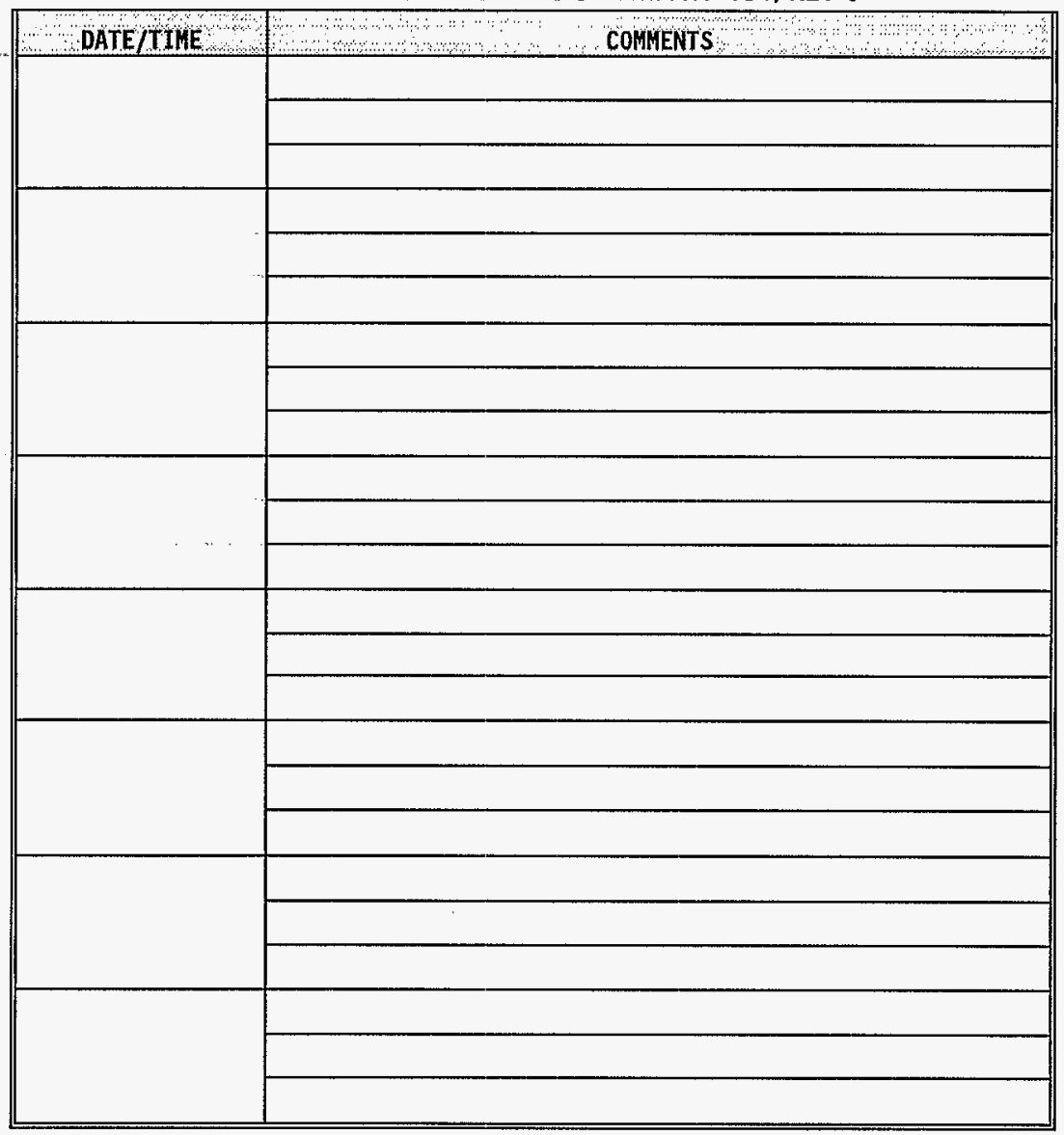


WHC-SD-WM-ATP-184

Revision 0

APPENDIX D TEST EXECUTION SHEET 
WHC-SD-WM-ATP-184

Revision 0

TEST EXECUTION SHEET

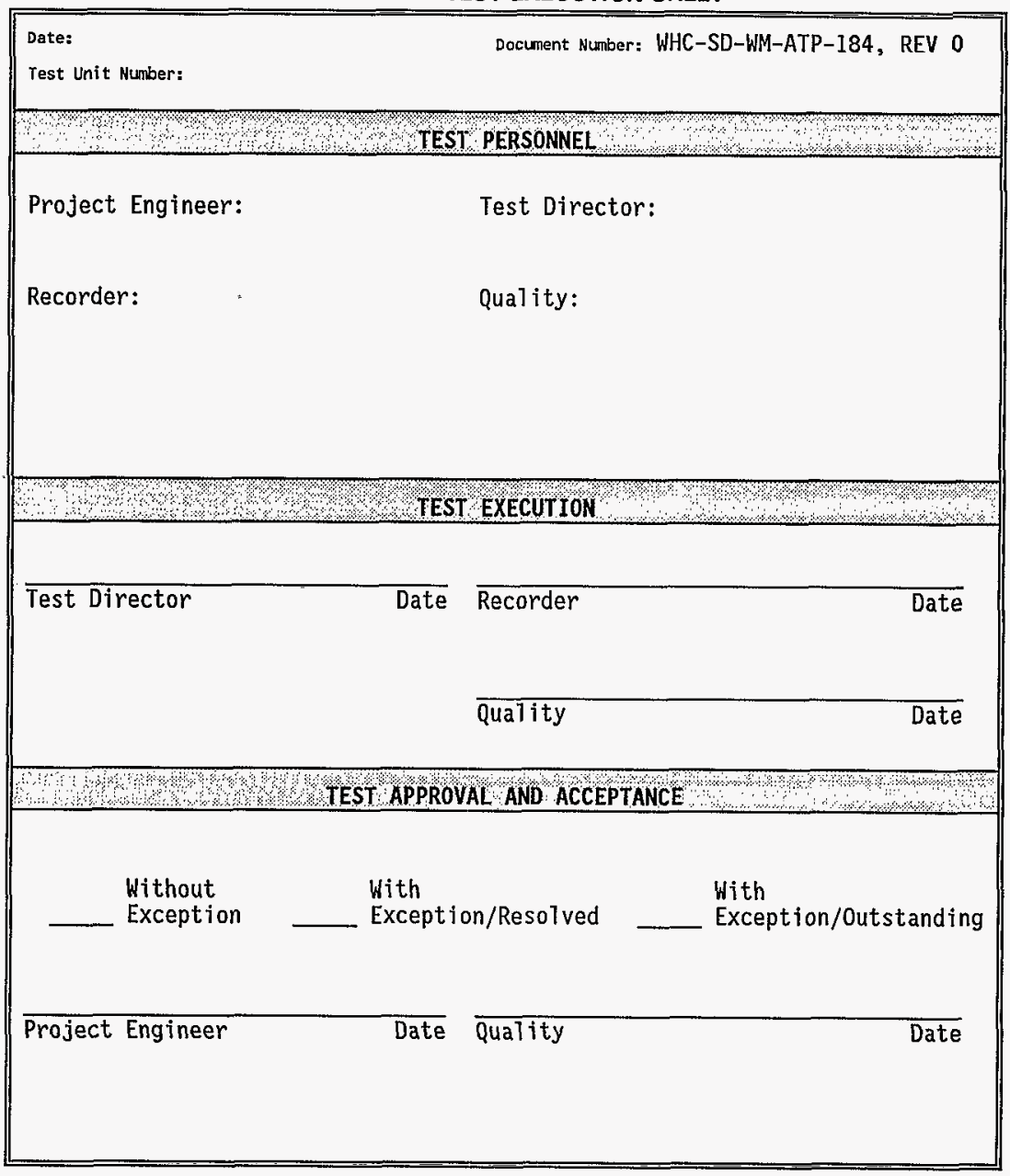




\section{DISTRIBUTION SHEET}

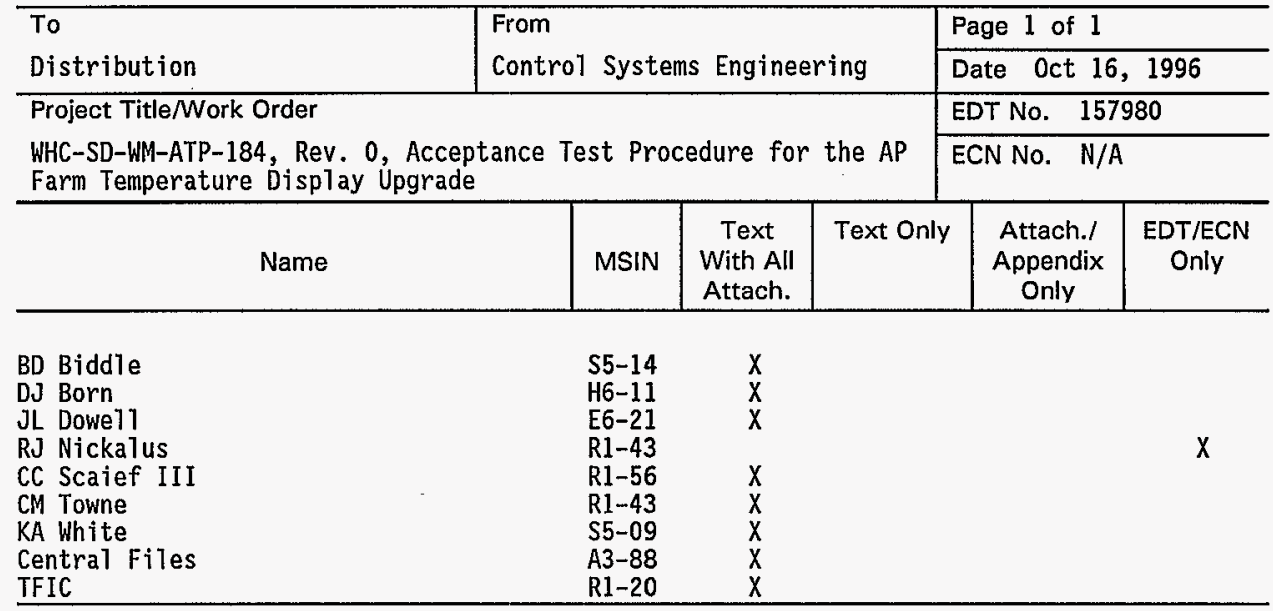

